\title{
HIV and HCV prevalence among entrants to methadone maintenance treatment clinics in China: a systematic review and meta-analysis
}

\author{
Xun Zhuang ${ }^{1,2}$, Yanxian Liang ${ }^{1}$, Eric PF Chow ${ }^{2}$, Yafei Wang ${ }^{1}$, David P Wilson ${ }^{2}$ and Lei Zhang ${ }^{2^{*}}$
}

\begin{abstract}
Background: Methadone maintenance treatment (MMT) was implemented in China since 2004. It was initiated in 8 pilot clinics and subsequently expanded to 738 clinics by the end of 2011. Numerous individual research studies have been conducted to estimate HIV and HCV prevalence among MMT clients but an overview of the epidemics in relations to MMT remains unclear. The aim of this study is to estimate the magnitude and changing trends of HIV, HCV and HIV-HCV co-infections among entry clients to MMT clinics in China during 2004-2010.

Methods: Chinese and English databases of literature were searched for studies reporting HIV, HCV and co-infection prevalence among MMT clients in China from 2004 to 2010. The prevalence estimates were summarized through a systematic review and meta-analysis of published literatures.

Results: Ninety eligible articles were selected in this review (2 in English and 88 in Chinese). Nationally, pooled prevalence of HIV-HCV and HIV-HCV co-infection among MMT clients was 6.0\% (95\%Cl: 4.7\%-7.7\%), 60.1\% (95\%Cl: 52.8\%-67.0\%) and 4.6\% (95\%Cl: 2.9\%-7.2\%), respectively. No significant temporal trend was found in pooled prevalence estimates. Study location is the major contributor of heterogeneities of both HIV and HCV prevalence among drug users in MMT.

Conclusions: There was no significant temporal trend in HIV and HCV prevalence among clients in MMT during 2004-2010. Prevalence of HCV is markedly higher than prevalence of HIV among MMT clients. It is recommended that health educational programs in China promote the earlier initiation and wider coverage of MMT among injecting drug users (IDUs), especially HIV-infected IDUs.
\end{abstract}

Keywords: HIV, HCV, Co-infection, Prevalence, Methadone maintenance treatment, Meta-analysis, China

\section{Background}

Since the implementation of open-door policies in 1979, illicit drug trade has re-emerged in China. As the most populous country in the world, China has observed a rapid increase in drug use over the past three decades [1]. The number of officially registered drug users increased from 70,000 in 1990 to 1.33 million at the end of 2009 [2]. Moreover, behind each registered drug user, there were estimated 2-4 implicit drug users [3]. Official statistics indicates that $73.2 \%$ of drug users in China in 2009 used heroin [2]. Intravenous injection is the most

\footnotetext{
* Correspondence: Izhang@kirby.unsw.edu.au

${ }^{2}$ The Kirby Institute, University of New South Wales, Sydney, Australia

Full list of author information is available at the end of the article
}

common mean of drug use, with injecting drug users (IDUs) accounting for 59-85\% of drug users [4-10].

Drug users (DUs), especially IDUs, represent a highrisk population for spreading HIV infection due to their high frequency of injection, sharing of contaminated needles and other risk behaviours [11-15]. The first domestic Chinese HIV/AIDS cases were found among heroin users in Yunnan Province as early as 1989 [16]. By the end of 2002, HIV cases among drug users were reported in all 31 Chinese provinces, autonomous regions and municipalities [4]. The cumulative number of diagnosed HIV/AIDS cases in China is now well over 200,000 , among which over $60 \%$ were drug users $[6,17]$. IDUs account for over $40 \%$ of new HIV infections $[6,17]$.

\section{Biomed Central}


In China, HIV prevalence has wide geographic variations. According to the Chinese national surveillance report for 1995-2009 [18], five provinces (Yunnan, Guizhou, Sichuan, Guangxi and Xinjiang) were classified as high transmission areas (HTAs) for HIV infection among drug users, and the rest of country was considered as low transmission areas (LTAs). HIV prevalence among drug users in Yunnan and Xinjiang were the highest among all Chinese provinces, of approximately $25 \%-30 \%$ in $2007[18,19]$. Similarly, HCV prevalence among DUs in China is high, but estimates vary substantially from $15.6 \%$ to $98.7 \%$ [20-23].

Harm reduction programs for drug users began in 2003 in China and it is believed that they have contributed to reductions in the spread of HIV [24-26]. A major component of this program is methadone maintenance treatment (MMT), which was initiated as a pilot program in 8 clinics serving 1,029 drug users in 2004 and subsequently expanded to 738 clinics serving 344,254 drug users by the end of 2011, which accounts for approximately $30 \%$ of registered IDUs in China (personal communication with China CDC). Initially, strict enrolment criteria were imposed to enroll only registered drug users [27]. In July 2006, new implementation protocol of the community-based MMT program has been announced by the Chinese Ministry of Health to cover a wider group of drug users [28]. The new protocol recommended MMT clinics also offer ancillary services including counseling and psychosocial support, testing for HIV and infections, referrals for antiretroviral treatment and other social supports [27].

There have been numerous independent studies documenting the prevalence of HIV or HCV among MMT clients at baseline of their treatment. Across these studies, large variations in $\mathrm{HIV}$ and $\mathrm{HCV}$ prevalence estimates were commonly observed, reflecting the complex geographical and chronological overlapping of the two epidemics. Numerous individual research studies have been conducted to estimate HIV and HCV prevalence among MMT clients in China. The studies vary in time and geographical locations, and do not provide a complete overview of HIV and HCV epidemics in relations to MMT in China. This study aims to investigate the geographical and the temporal patterns of HIV and HCV epidemics in China and their likely interaction. We do this through a systematic review and meta-analysis and we also discuss implications for future MMT implementation and health policies for HIV prevention among IDUs in China.

\section{Methods}

\section{Search strategy}

Two independent investigators conducted a systematic review of published peer-reviewed research articles by searching the following databases: PubMed, Chinese
Scientific Journals Fulltext Database (CQVIP), China National Knowledge Infrastructure (CNKI) and Wanfang Data from 2004-2010. Keywords used in the database search included ("Methadone" OR "Methadone Maintenance Treatment" $O R$ "Methadone Maintenance Therapy" $O R$ "Methadone Maintenance") AND ("HIV" OR "AIDS" $O R$ "HCV" $O R$ "hepatitis C virus" $O R$ "co-infection") $A N D$ ("China" $O R$ "China Mainland"). We also performed a manual search of the reference lists of published articles. This review was conducted and reported according to the PRISMA (Preferred Reporting Items for Systematic Reviews and Meta-Analyses) Statement issued in 2009 [29].

\section{Study selection}

Studies were eligible for inclusion in this systematic review if they met the following criteria: (1) study published in Chinese or English language; (2) study reported HIV or $\mathrm{HCV}$ prevalence estimates among clients in MMT at baseline of treatment in China; (3) HIV and HCV infection must be diagnosed from laboratory serologic testing; (4) study design such as study site, time period and sample size must be reported. Intervention studies among MMT clients were also included. Exclusion criteria were: (1) review papers; (2) non peer-reviewed local/government reports; (3) conference abstracts and presentations; (4) self-reported HIV or HCV infections; (5) dissertations. If the same study data were published in both English and Chinese sources, the articles published in Chinese language were excluded from this study.

\section{Validity assessment}

The quality of studies was assessed using a validated quality assessment tool for cross-sectional studies [30]. The following eight items were assessed to calculate a total quality score: (1) clear definition of the target population; (2) representativeness of probability sampling; (3) sample characteristics matching the overall population; (4) adequate response rate; (5) standardized data collection methods; (6) reliable of survey measures/ instruments; (7) valid of survey measures/instruments; (8) appropriate statistical methods. Answers were scored 0 and 1 for 'No' and 'Yes', respectively. The total quality score varied between 0 and 8 for each study.

\section{Data abstraction}

We extracted the following information from all eligible studies: published year, study site, study period, gender, age, marital status, education, study design, clients recruitment methods, sample size; laboratory test methods for HIV and HCV, prevalence of HIV, HCV and HIV$\mathrm{HCV}$ co-infection among MMT clients at the baseline of the treatment. The studies were then categorized by geographical locations according to their level of HIV 
transmission, and also into two specific time periods, prior to and after 2006.

\section{Statistical analysis}

Meta-analyses were carried out with the Comprehensive Meta-Analysis software (V2.0, Biostat, Englewood, New Jersey). The effect rates of pooled prevalence estimates and $95 \%$ confidence intervals $(\mathrm{CI})$ were determined based on random effect models. Random effect models were applied when heterogeneity across subgroups were found to be significant. Heterogeneity tests were performed using the Cochran Q-test $(p<0.10$ represents statistically significant heterogeneity) and $I^{2}$ statistic. We investigated the factors that are associated with heterogeneities in the stratified meta-analyses using meta-regression. Meta- regression was performed in STATA 10.0 (StataCrop, Texas, USA) Potential publication bias was measured by the Begg and Mazumdar rank correlation $(p<0.05)$. Spearmen correlation was used to assess the relationship between HIV prevalence and HCV prevalence among clients in MMT in China.

\section{Results}

Trial flow/flow of included studies

A total of 834 studies were identified from four electronic databases (62 in PubMed, 410 in CNKI, 144 in CQVIP, 218 in Wanfang database). Due to duplication and irrelevance, we excluded 478 articles after screening the titles. We screened the abstracts of the remaining 356 articles, following which 216 articles were excluded

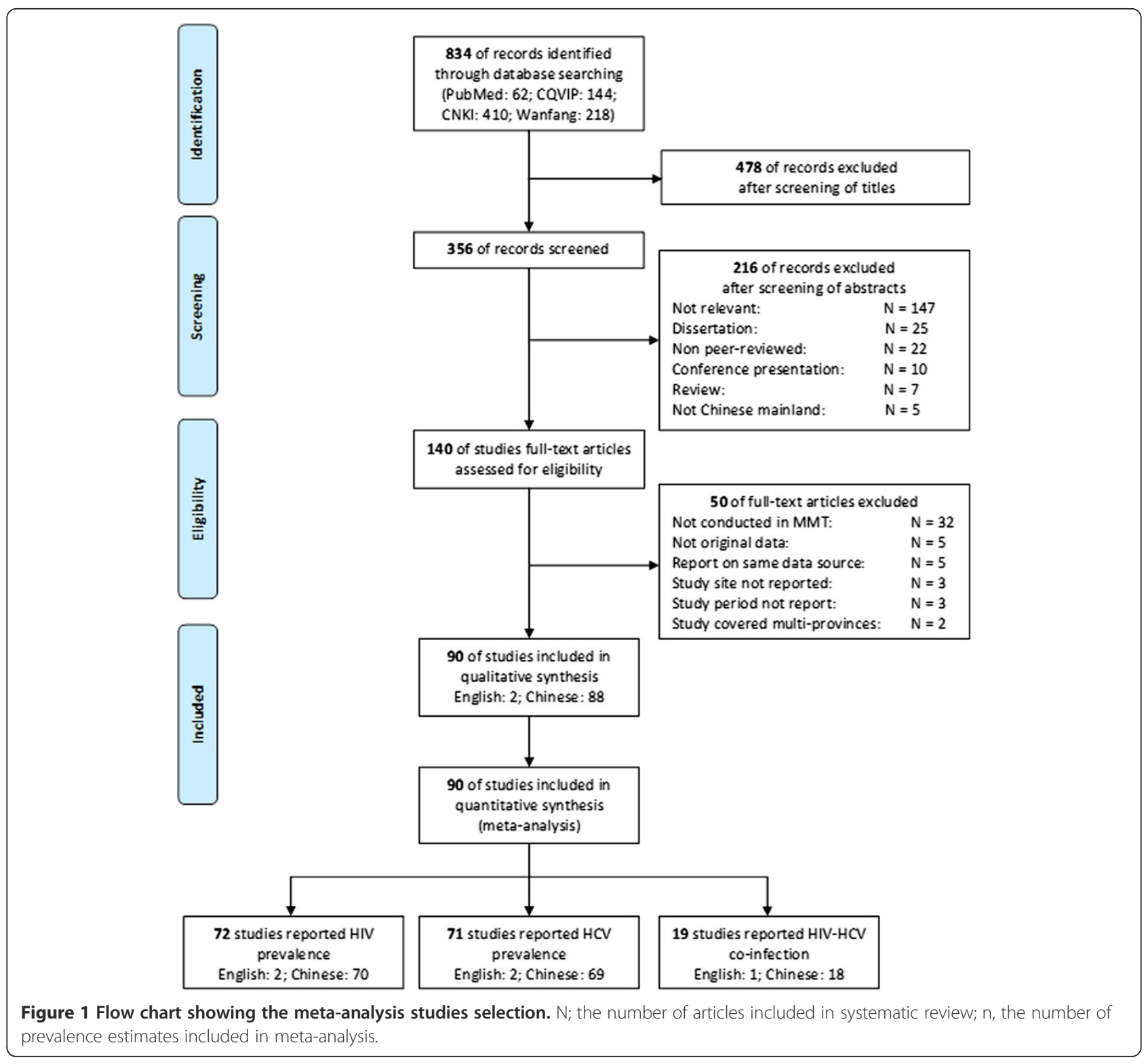


Table 1 Summary of HIV prevalence among clients in MMT in China

\begin{tabular}{|c|c|c|c|c|c|c|}
\hline Groups & Provinces & $\begin{array}{c}\text { No of } \\
\text { studies }\end{array}$ & $\begin{array}{l}\text { Study } \\
\text { Year }\end{array}$ & $\begin{array}{l}\text { Prevalence (individual } \\
\text { studies) }(95 \% \mathrm{Cl})\end{array}$ & $\begin{array}{l}\text { Pooled prevalence } \\
\text { (provinces) }(95 \% \mathrm{Cl})\end{array}$ & $\begin{array}{c}\text { Pooled prevalence } \\
\text { (group) }(95 \% \mathrm{CI}) \\
\end{array}$ \\
\hline \multirow[t]{32}{*}{ HTAs } & Guangxi & 3 & & & $17.7 \%(7.2-37.4 \%)$ & $17.5 \%(14.0-21.6 \%)$ \\
\hline & Zhou XP, 2009 [31] & & 2007 & $28.2 \%(22.0-35.5 \%)$ & & \\
\hline & Chang ZR, 2010 [32] & & 2008 & $27.9 \%$ (25.2-30.7\%) & & \\
\hline & Bai Y, 2009 [33] & & 2009 & $6.0 \%(4.2-8.4 \%)$ & & \\
\hline & Guizhou & 4 & & & $20.7 \%$ (14.2-29.2\%) & \\
\hline & Chang ZR, 2010 [32] & & 2008 & $24.6 \%$ (21.5-28.1\%) & & \\
\hline & $\operatorname{Han}$ XJ, 2010 [34] & & 2009 & $27.0 \%(22.3-32.2 \%)$ & & \\
\hline & Li XY, 2009 [35] & & 2009 & $0.5 \%(0.1-3.5 \%)$ & & \\
\hline & Wang J, 2010 [36] & & 2009 & $20.3 \%(14.5-27.7 \%)$ & & \\
\hline & Sichuan & 8 & & & $7.1 \%(3.8-12.9 \%)$ & \\
\hline & Hao C, 2006 [37] & & 2004 & $13.6 \%$ (10.4-17.6\%) & & \\
\hline & Qian HZ, 2007 [38] & & 2005 & $14.0 \%(11.4-17.1 \%)$ & & \\
\hline & Chen B, 2009 [39] & & 2006 & $2.0 \%(1.0-3.9 \%)$ & & \\
\hline & Liu JK, 2009 [40] & & 2006 & $14.1 \%(8.2-23.2 \%)$ & & \\
\hline & Dong G, 2009 [41] & & 2007 & $4.3 \%(2.6-7.0 \%)$ & & \\
\hline & Wang Y, 2009 [42] & & 2008 & $3.8 \%(2.6-5.5 \%)$ & & \\
\hline & Wang DY, 2009 [43] & & 2008 & $21.7 \%$ (18.9-24.9\%) & & \\
\hline & Yao W, 2008 [44] & & 2008 & $2.3 \%(1.4-3.6 \%)$ & & \\
\hline & Xinjiang & 6 & & & $22.0 \%(15.2-30.6 \%)$ & \\
\hline & Liu JB, 2006 [45] & & 2005 & 19.4\% (13.4-27.1\%) & & \\
\hline & Fu LP, 2007 [46] & & 2006 & $33.4 \%$ (29.7-37.3\%) & & \\
\hline & Fang HR, 2008 [47] & & 2008 & $14.2 \%(12.6-16.1 \%)$ & & \\
\hline & Re ZW, 2009 [48] & & 2008 & $28.6 \%$ (22.4-35.7\%) & & \\
\hline & Shen L, 2009 [49] & & 2008 & $14.9 \%$ (12.8-17.3\%) & & \\
\hline & Yuan L, 2010 [50] & & 2008 & $26.55(20.8-33.0 \%)$ & & \\
\hline & Yunnan & 6 & & & $36.0 \%$ (25.6-47.9\%) & \\
\hline & Duan YJ, 2008 [51] & & 2006 & $33.3 \%$ (24.8-43.2\%) & & \\
\hline & Zhang MJ, 2008 [52] & & 2007 & $51.8 \%(44.2-59.3 \%)$ & & \\
\hline & Zhuang HY, 2008 [53] & & 2007 & $66.7 \%$ (51.8-78.8\%) & & \\
\hline & Xue HM, 2010 [54] & & 2008 & $39.3 \%$ (37.1-41.5\%) & & \\
\hline & Yang GW, 2010 [55] & & 2008 & $15.7 \%(11.4-21.3 \%)$ & & \\
\hline & Yang YC, 2011 [56] & & 2009 & $23.1 \%(21.7-24.5 \%)$ & & \\
\hline \multirow[t]{9}{*}{ LTAs } & Beijing & 1 & & & $4.6 \%$ (2.7-7.8\%) & $2.4 \%(1.6-3.5 \%)$ \\
\hline & Du WJ, 2007 [57] & & 2005 & $4.6 \%$ (2.7-7.8\%) & & \\
\hline & Chongqing & 3 & & & $6.8 \%(4.3-10.6 \%)$ & \\
\hline & Tan XL, 2007 [58] & & 2005 & 7.8\% (5.5-11.0\%) & & \\
\hline & Wu GH, 2010 [59] & & 2007 & $9.2 \%(7.1-11.8 \%)$ & & \\
\hline & Zhou X, 2009 [60] & & 2008 & $4.3 \%(3.0-6.1 \%)$ & & \\
\hline & Fujian & 2 & & & $2.1 \%(1.1-3.9 \%)$ & \\
\hline & Wu LH, 2007 [61] & & 2006 & $2.0 \%(0.5-7.6 \%)$ & & \\
\hline & Zheng WX, 2009 [62] & & 2006 & $2.1 \%(1.0-4.3 \%)$ & & \\
\hline
\end{tabular}


Table 1 Summary of HIV prevalence among clients in MMT in China (Continued)

\begin{tabular}{|c|c|c|c|c|}
\hline Gansu & 2 & & & $0.7 \%(0.3-1.5 \%)$ \\
\hline Gao LF, 2010 [63] & & 2009 & $0.8 \%(0.2-3.2 \%)$ & \\
\hline Zhu XH, 2010 [64] & & 2010 & $0.7 \%(0.2-1.7 \%)$ & \\
\hline Guangdong & 13 & & & $3.6 \%(1.6-8.3 \%)$ \\
\hline Dai LP, 2009 [65] & & 2007 & $5.9 \%(2.7-12.6 \%)$ & \\
\hline Liu XY, 2009 [66] & & 2007 & $1.2 \%(1.0-1.5 \%)$ & \\
\hline Zhang QL, 2008 [67] & & 2007 & $0.2 \%(0.0-3.8 \%)$ & \\
\hline Chen W, 2009 [68] & & 2008 & $20.7 \%(17.2-24.7 \%)$ & \\
\hline Chen A, 2007 [69] & & 2008 & $19.6 \%(16.4-23.3 \%)$ & \\
\hline Dai LP, 2010 [70] & & 2008 & $3.5 \%(1.8-6.6 \%)$ & \\
\hline Hu WS, 2010 [71] & & 2008 & $9.6 \%$ (5.5-16.1\%) & \\
\hline Li LY, 2009 [72] & & 2008 & $1.0 \%(0.1-6.8 \%)$ & \\
\hline Li YF, 2009 [73] & & 2008 & $2.5 \%(1.0-5.9 \%)$ & \\
\hline Wang M, 2009 [74] & & 2008 & $1.3 \%(0.1-17.5 \%)$ & \\
\hline Wang CQ, 2009 [75] & & 2009 & $1.9 \%(1.0-3.8 \%)$ & \\
\hline Wu ZL, 2010 [76] & & 2009 & 7.9\% (5.8-10.6\%) & \\
\hline Xia L, 2010 [77] & & 2009 & $1.2 \%(0.4-3.7 \%)$ & \\
\hline Henan & 1 & & & $0.9 \%(0.2-3.6 \%)$ \\
\hline Wu SX, 2009 [78] & & 2008 & $0.9 \%(0.2-3.6 \%)$ & \\
\hline Hubei & 1 & & & $0.1 \%(0.0-1.8 \%)$ \\
\hline Qiu XQ, 2009 [79] & & 2006 & $0.1 \%(0.0-1.8 \%)$ & \\
\hline Hunan & 7 & & & $6.9 \%(4.1-11.4 \%)$ \\
\hline Li XL, 2008 [80] & & 2006 & $1.2 \%(0.3-4.7 \%)$ & \\
\hline Li XL, 2009 [81] & & 2006 & $16.7 \%$ (14.2-19.7\%) & \\
\hline Tang XY, 2007 [82] & & 2006 & $14.7 \%(10.2-20.7 \%)$ & \\
\hline Chen LF, 2009 [83] & & 2007 & $13.7 \%(10.3-18.1 \%)$ & \\
\hline He HX, 2008 [84] & & 2007 & $9.5 \%(7.5-12.0 \%)$ & \\
\hline Chen C, 2010 [85] & & 2008 & $1.9 \%(0.5-7.2 \%)$ & \\
\hline Feng YH, 2010 [86] & & 2009 & $0.6 \%(0.2-1.8 \%)$ & \\
\hline Jiangsu & 6 & & & $0.9 \%(0.5-1.5 \%)$ \\
\hline Wang YP, 2009 [87] & & 2007 & $1.4 \%(0.5-4.3 \%)$ & \\
\hline Feng SQ, 2010 [88] & & 2008 & $1.1 \%(0.4-2.8 \%)$ & \\
\hline Hao C, 2009 [89] & & 2008 & $0.6 \%(0.2-1.6 \%)$ & \\
\hline Xu GY, 2008 [90] & & 2008 & $0.5 \%(0.0-7.3 \%)$ & \\
\hline Zhang MH, 2010 [91] & & 2008 & $1.0 \%(0.3-3.0 \%)$ & \\
\hline Yuan ZX, 2010 [92] & & 2009 & $0.2 \%(0.0-3.4 \%)$ & \\
\hline Ningxia & 1 & & & $1.2 \%(0.5-2.6 \%)$ \\
\hline Jiang A, 2009 [93] & & 2007 & $1.2 \%(0.5-2.6 \%)$ & \\
\hline Qinghai & 1 & & & $1.4 \%(0.5-3.8 \%)$ \\
\hline Hao XQ, 2009 [94] & & 2008 & $1.4 \%(0.5-3.8 \%)$ & \\
\hline Shaanxi & 2 & & & $1.4 \%(0.5-3.8 \%)$ \\
\hline Jia W, 2008 [95] & & 2006 & $1.7 \%(0.7-3.9 \%)$ & \\
\hline Zhang HF, 2009 [96] & & 2008 & $0.4 \%(0.0-6.3 \%)$ & \\
\hline Shanghai & 2 & & & $1.4 \%(0.5-4.8 \%)$ \\
\hline Liu Y, 2009 [97] & & 2008 & $1.5 \%(0.5-4.4 \%)$ & \\
\hline Li T, 2010 [98] & & 2009 & $1.0 \%(0.1-13.6 \%)$ & \\
\hline
\end{tabular}


Table 1 Summary of HIV prevalence among clients in MMT in China (Continued)

\begin{tabular}{llll} 
Zhejiang & 3 & & \\
Cai CP, 2008 [99] & & 2007 & $0.5 \%(0.1-1.6 \%)$ \\
Zhang XH, 2008 [100] & 2007 & $0.6 \%(0.1-4.2 \%)$ & \\
Su MF, 2010 [101] & 2009 & $0.3 \%(0.0-2.3 \%)$ & \\
\hline
\end{tabular}

(147 were not relevant, 25 were dissertations, 22 were non peer-reviewed theses, 10 were conference presentations or abstracts, 7 were reviews or letters and 5 were not carried out in mainland China). Among the remaining 140 articles eligible for full-text screening; we further excluded 50 articles (32 were not conducted among MMT clients, 5 did not report original data, 5 reported results from already identified data sources, 3 did not report study sites, 3 did not report study period, 2 studies covered multiple provinces). We finally included 90 articles ( 2 in English and 88 in Chinese) for subsequent quantitative synthesis, of which, 72, 71 and 19 articles were eligible for meta-analysis of HIV, HCV and HIV-HCV co-infection prevalence, respectively. The selection process is illustrated in Figure 1 and the quality score of each study is shown in the Additional file 1: Table S1.

\section{Study characteristics}

The 90 eligible articles were from 19 of the 31 Chinese provinces. The sample size of the selected studies ranged from 38 to 8662 (median: 300; IQR: 175-512). All participants were recruited from MMT clinics. Eighty-one out of 90 studies (90\%) were cross-sectional, 5 (6\%) were cohort studies, 2 (2\%) were randomized controlled trials and $2(2 \%)$ did not report the study design. There were 72, 71 and 19 prevalence estimates on HIV, HCV and HIV-HCV co-infection among MMT clients at baseline of treatment respectively.

\section{Epidemic trends of HIV, HCV infection and HIV-HCV co-infection}

The overall national prevalence of HIV, HCV and HIV$\mathrm{HCV}$ co-infection among MMT clients at baseline of treatment in China were 6.0\% (95\% CI: 4.7-7.7\%), 60.1\% (95\% CI: $52.8-67.0 \%)$ and $4.6 \%$ (95\% CI: $2.9-7.2 \%)$ respectively. Prevalence in HTAs were consistently higher than those in LTAs (HIV: $17.5 \%$ (95\% CI: 14.0-21.6\%) vs. 2.4\% (95\% CI: 1.6-3.5\%); HCV: 70.2\% (95\% CI: 62.676.8\%) vs. $55.5 \%$ (95\% CI: 46.4-64.2\%); HIV-HCV coinfection: $8.0 \%$ (95\% CI: $4.8-12.9 \%)$ vs. $2.5 \%$ (95\% CI: 1.4-4.4\%)). Large variations in prevalence were also observed geographically. Whereas HIV prevalence among MMT clients varied from 0.1\% (Hubei) to 36.0\% (Yunnan) (Table 1, Figure 2a), HCV prevalence varied from $10.9 \%$ (Henan) to $65.7 \%$ (Guangxi) (Table 2,
Figure 2b) and HIV-HCV co-infection varied from $0.5 \%$ (Henan) to $12.6 \%$ (Guangxi) (Table 3, Figure 2c). The forest plots showing the results of meta-analysis of HIV, $\mathrm{HCV}$ and HIV-HCV co-infection prevalence among clients in MMT are illustrated in the Additional file 1: Figure S1, S2 and S3. However, no temporal trends of any of these infections were found at the national level, in HTAs or LTAs since the initiation of MMT in 2004.

Our analysis reported high heterogeneities across the collected studies in evaluation of the pooled prevalence of the infections (HIV: $I^{2}=97.614, \quad p<0.001$; HCV: $I^{2}=99.163, p<0.001$; HIV-HCV $\left.: I^{2}=96.671 ; p<0.001\right)$. For HIV and HCV infections, meta-regression demonstrated that these heterogeneities were mainly contributed by the geographical locations of the studies and contributions from study language, sample size, sampling method and study time period were not significant. In contrast, studies with sampling sizes greater than 500 tended to report higher HIV-HCV co-infection rates than otherwise and the influence of geographical location was marginal (Table 4). No publication bias was found across the 72, 71 and 19 studies reported HIV, HCV and HIV-HCV coinfection (Begg rank correlation analysis $p=0.163,0.702$ and 0.649 , respectively). A significantly positive correlation (Spearman, $r=0.456, p<0.001$ ) was observed between HIV and HCV prevalence among clients in Chinese MMT during 2004-2010 countrywide.

\section{Discussion}

Consistent with findings from national sentinel surveillance [18], our meta-analyses indicated that HIV and $\mathrm{HCV}$ prevalence in MMT is distinctly higher in HTAs. This confirms that the prevalence of these infections remained highly concentrated among provinces along the traditional drug-trafficking routes but are considerably lower in the rest of the country.

Our estimated national HIV prevalence of $6.0 \%$ (95\% CI: 4.7-7.7\%) among people in MMT is not significantly different to the estimated HIV prevalence among nonMMT drug users (4.6-7.5\%) reported by national sentinel surveillance during 2004-2009 [18]. We noticed that HIV prevalence among people in MMT in Sichuan (7.1\%) and Guizhou (20.7\%) province is higher than that from sentinel surveillance data [2,27,121-123], indicating that methadone clinics in these areas may have recruited more HIV-positive patients among drug users [124]. 

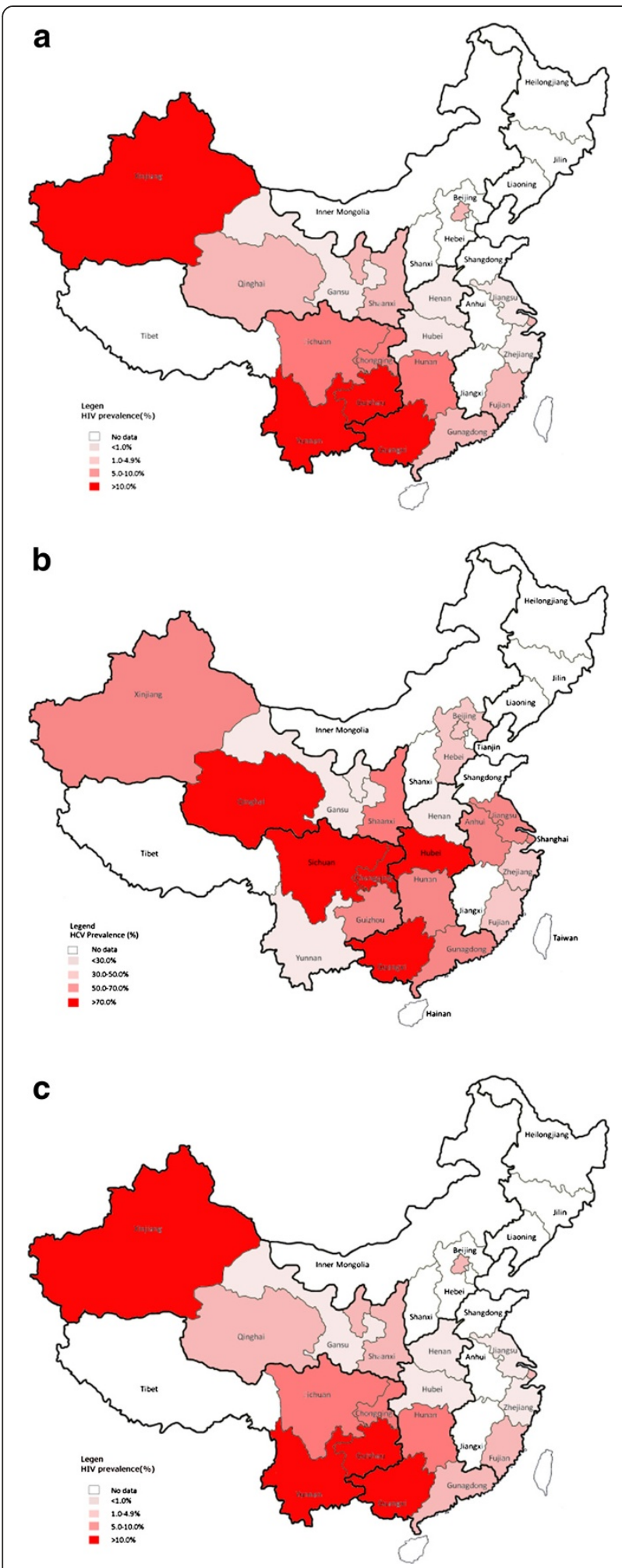

Figure 2 The regional distribution of pooled prevalence of (a) HIV infection; (b) HCV infection; and (c) HIV-HCV co-infection in MMT in China.
Additionally, our stratified time analysis of HIV, HCV and HIV-HCV co-infection among MMT clients did not show significant temporal trends in the prevalence of these infections since initiation of MMT in 2004. This suggested that the 2006 national policy to relax the eligibility criteria for MMT enrollment was not sufficient to encourage more HIV-infected drug users to participate in the program. MMT is known to significantly reduce the consumption of heroin and associated risk behaviours of the participants [24,125-129]. It is therefore in the best interest of the Chinese government to substantially scale-up the proportion of HIV-infected participants in MMT. The consequent reduction in risk behaviours of the infected population may help to confine the transmission sources of HIV infection. In order to achieve this, more comprehensive services, such as referral services, counseling, social supports targeting HIV-infected drug users etc., should be provided. Educational programs to reduce social stigma as well as psychological barriers for treatment adherence especially for HIV-infected drug users should be implemented.

Our analysis indicated a national $\mathrm{HCV}$ prevalence of 59.9\% (95\% CI: 52.7-66.7\%) among MMT clients in China. This result is higher than the reported prevalence of $50.4 \%$ (95\% CI: $42.5-58.4 \%$ ) in a recent meta-analysis [130], in which the subjects were selected not only from MMT, but also from detoxification centers and the community. Chinese sentinel surveillance did not start monitoring HCV among drug users until 2009 and there have been no data currently published. Consistent with findings in other settings, HCV prevalence is positively correlated with HIV prevalence among MMT clients in China $[89,130,131]$. The fact that HCV prevalence was found to be 10 times higher than HIV prevalence may be due to a number of reasons. Biologically, transmission efficiency of blood-borne HCV has been estimated to be approximately 10 times greater than that of HIV for needle-stick injuries [132]. Secondly, HCV infection may have entered drug users population much earlier and hence already established a stabilized epidemic in China $[131,133]$. With a large number of chronic HCV-infected individuals in the drug user communities, a susceptible person may be more prone to the infection through needle-sharing with other IDUs.

The prevalence of HIV-HCV co-infection and HIV were not markedly different suggesting that a large proportion of HIV-infected MMT clients in China are also infected with HCV. Studies have shown that the coinfection of these diseases interact synergistically and the presence of each infection can substantially reduce the immune clearance of the other [134-136]. HCV coinfection may accelerate the progression to AIDS stage and death [134], even among people with continuous suppression of HIV replication [137]. It also blunts the 
Table 2 Summary of HCV prevalence among clients in MMT in China

\begin{tabular}{|c|c|c|c|c|c|c|}
\hline Groups & Provinces & $\begin{array}{l}\text { No of } \\
\text { studies }\end{array}$ & $\begin{array}{l}\text { Study } \\
\text { Year }\end{array}$ & $\begin{array}{c}\text { Prevalence (individual } \\
\text { studies) }(95 \% \mathrm{Cl})\end{array}$ & $\begin{array}{l}\text { Pooled prevalence } \\
\text { (provinces) }(95 \% \mathrm{Cl})\end{array}$ & $\begin{array}{l}\text { Pooled prevalence } \\
\text { (group) }(95 \% \mathrm{Cl})\end{array}$ \\
\hline \multirow[t]{26}{*}{ HTAs } & Guangxi & 3 & & & $87.2 \%$ (85.4-88.8\%) & $70.2 \%$ (62.6-76.8\%) \\
\hline & Zhou XP, 2009 [31] & & 2007 & 88.8\% (83.1-92.8\%) & & \\
\hline & Chang ZR, 2010 [32] & & 2008 & $87.9 \%$ (85.5-89.8\%) & & \\
\hline & Bai Y, 2009 [33] & & 2009 & $85.5 \%(82.2-88.3 \%)$ & & \\
\hline & Guizhou & 6 & & & $61.5 \%(46.1-75.0 \%)$ & \\
\hline & Chang ZR, 2010 [32] & & 2008 & $76.1 \%$ (72.7-79.3\%) & & \\
\hline & Wang J, 2008 [102] & & 2008 & $41.6 \%$ (34.6-48.9\%) & & \\
\hline & Deng CK, 2009 [103] & & 2008 & $61.4 \%$ (55.9-66.7\%) & & \\
\hline & Han XJ, 2010 [34] & & 2009 & $60.0 \%(54.4-65.4 \%)$ & & \\
\hline & Li XY, 2009 [35] & & 2009 & $33.5 \%(27.3-40.4 \%)$ & & \\
\hline & Wang J, 2010 [36] & & 2009 & $86.7 \%$ (80.1-91.4\%) & & \\
\hline & Sichuan & 6 & & & $77.4 \%$ (71.0-82.8\%) & \\
\hline & Hao C, 2006 [37] & & 2004 & $67.3 \%$ (62.2-72.1\%) & & \\
\hline & Qian HZ, 2007 [38] & & 2005 & $68.4 \%(64.4-72.1 \%)$ & & \\
\hline & Dong G, 2009 [41] & & 2007 & $78.6 \%$ (74.0-82.6\%) & & \\
\hline & Wang DY, 2009 [43] & & 2008 & 83.7\% (80.7-86.2\%) & & \\
\hline & Yao W, 2008 [44] & & 2008 & $82.9 \%(80.0-85.4 \%)$ & & \\
\hline & Zhao XH, 2009 [104] & & 2008 & $80.1 \%$ (75.9-83.7\%) & & \\
\hline & Xinjiang & 5 & & & $64.8 \%(50.0-77.2 \%)$ & \\
\hline & Liu JB, 2006 [45] & & 2005 & $69.0 \%(60.5-76.4 \%)$ & & \\
\hline & Fu LP, 2007 [46] & & 2006 & $40.0 \%$ (36.1-44.0\%) & & \\
\hline & Fang HR, 2008 [47] & & 2008 & $68.9 \%(66.5-71.2 \%)$ & & \\
\hline & Yuan L, 2010 [50] & & 2008 & $72.0 \%$ (65.4-77.8\%) & & \\
\hline & Re ZW, 2009 [48] & & 2008 & $72.0 \%$ (64.9-78.2\%) & & \\
\hline & Yunnan & 1 & & & $23.8 \%(18.5-30.0 \%)$ & \\
\hline & Yang GW, 2010 [55] & & 2008 & $23.8 \%(18.5-30.0 \%)$ & & \\
\hline \multirow[t]{15}{*}{ LTAs } & Anhui & 2 & & & $62.3 \%(17.0-93.0 \%)$ & $55.5 \%(46.4-64.2 \%)$ \\
\hline & Wang XR, 2007 [105] & & 2007 & $36.4 \%(31.0-42.2 \%)$ & & \\
\hline & Zhan SW, 2008 [106] & & 2007 & $82.8 \%(77.1-87.3 \%)$ & & \\
\hline & Beijing & 1 & & & $46.4 \%(40.7-52.3 \%)$ & \\
\hline & Du WJ, 2007 [57] & & 2005 & $46.4 \%$ (40.7-52.3\%) & & \\
\hline & Chongqing & 2 & & & $76.2 \%$ (73.6-78.5\%) & \\
\hline & Zhou X, 2009 [60] & & 2007 & $74.7 \%$ (71.0-78.1\%) & & \\
\hline & Wu GH, 2010 [59] & & 2008 & $77.2 \%$ (74.3-79.9\%) & & \\
\hline & Fujian & 2 & & & $48.4 \%$ (26.2-71.1\%) & \\
\hline & Wu LH, 2007 [61] & & 2006 & $36.0 \%(27.2-45.8 \%)$ & & \\
\hline & Zheng WX, 2009 [62] & & 2006 & $60.2 \%(54.8-65.3 \%)$ & & \\
\hline & Gansu & 3 & & & $23.7 \%$ (18.0-30.7\%) & \\
\hline & Gao LF, 2010 [63] & & 2009 & $23.8 \%(18.9-29.5 \%)$ & & \\
\hline & He XX, 2010 [107] & & 2009 & $19.5 \%(17.6-21.6 \%)$ & & \\
\hline & Zhu XH, 2010 [64] & & 2010 & $28.7 \%(25.3-32.4 \%)$ & & \\
\hline
\end{tabular}


Table 2 Summary of HCV prevalence among clients in MMT in China (Continued)

\section{Guangdong \\ 8}

Liu XY, 2009 [66]

Zhang QL, 2008 [67]

Hu WS, $2010[71]$

Li LY, 2009 [72]

Li YF, 2009 [73]

Wang M, 2009 [74]

Wang CQ, 2009 [75]

Xia L, 2010 [77]

\section{Henan}

Wu SX, 2009 [78]

\section{Hubei}

Peng JS, 2007 [108]

\section{Hunan}

Li XL, 2008 [80]

He HX, 2008 [84]

Chen LF, 2009 [83]

Chen C, 2010 [85]

Feng YH, 2010 [86]

\section{Jiangsu}

Xia X, 2007 [109]

Xu YP, 2007 [110]

Wang YP, 2009 [87]

Feng SQ, 2010 [88]

Hao C, 2009 [89]

Song HB, 2010 [111]

Xu GY, 2008 [90]

Zhang MH, 2010 [91]

Yuan ZX, 2010 [92]

Wang WM, 2010 [112]

\section{Ningxia}

Jiang A, 2009 [93]

Liu XP, 2010 [113]

\section{Qinghai}

Hao XQ, 2009 [94]

\section{Shaanxi}

$$
\text { Jia W, } 2008 \text { [95] }
$$

Li YC, 2009 [114]

Zhang HF, 2009 [96]

Zang JF, 2010 [115]

Liu HB, 2010 [116]

\section{Shanghai}

Liu Y, 2009 [97]

Du J, 2009 [117]
2007

2007

2008

2008

2008

2008

2009

2009

1

1

2008 1

2006

2006

2007

2007

2008

2009

10

2006

2006

2007

2008

2008

2008

2008

2008

2009

2010

2

2007

2009

2008

2006

2008

2008

2009

2010

2

2008

2009
63.7\% (25.2-90.1\%)

5.4\% (4.9-5.9\%)

$30.3 \%(24.4-37.0 \%)$

96.0\% (90.7-98.3\%)

$67.0 \%(57.2-75.5 \%)$

$77.0 \%(70.7-82.3 \%)$

$81.6 \%$ (66.1-91.0\%)

$77.3 \%(73.0-81.0 \%)$

$62.2 \%(56.1-68.1 \%)$

10.9\% (7.4-15.8\%)

$10.9 \%(7.4-15.8 \%)$

$94.3 \%(91.2-96.3 \%)$

94.3\% (91.2-96.3\%)

$66.4 \%(49.3-80.1 \%)$

49.4\% (41.8-57.0\%)

$58.3 \%(54.5-62.0 \%)$

$59.5 \%(54.9-63.9 \%)$

$51.4 \%(42.0-60.7 \%)$

$93.7 \%$ (91.2-95.5\%)

61.6\% (51.8-70.6\%)

$35.0 \%(32.6-37.6 \%)$

$61.0 \%(56.1-65.6 \%)$

$70.5 \%(64.0-76.3 \%)$

$52.3 \%(47.2-57.3 \%)$

$51.8 \%(47.9-55.6 \%)$

66.2\% (59.6-72.2\%)

$76.2 \%(67.0-83.5 \%)$

$75.1 \%$ (70.0-79.6\%)

$56.5 \%(50.1-63.0 \%)$

$68.8 \%(62.3-74.7 \%)$

$23.0 \%(16.7-30.9 \%)$

$20.3 \%(17.0-24.0 \%)$

28.0\% (19.8-37.9\%)

$70.8 \%$ (65.1-75.8\%)

$70.8 \%(65.1-75.8 \%)$

$55.3 \%(43.2-66.7 \%)$

54.0\% (48.3-59.6\%)

$60.6 \%(55.8-65.3 \%)$

40.0\% (31.6-49.0\%)

$42.6 \%$ (30.9-55.2\%)

$73.8 \%$ (69.7-77.5\%)

$59.7 \%(54.2-64.9 \%)$

$61.2 \%(54.3-67.6 \%)$

$57.0 \%(47.8-65.8 \%)$ 
Table 2 Summary of HCV prevalence among clients in MMT in China (Continued)

$\begin{array}{llll}\text { Zhejiang } & 5 & & \\ \text { Zhang XH, 2007 [118] } & 2006 & 28.9 \%(16.8-45.1 \%) & 40.1 \%(24.7-57.8 \%) \\ \text { Cai CP, 2008 [99] } & 2007 & 75.9 \%(65.8-83.7 \%) \\ \text { Zhang XH, 2008 [110] } & 2007 & 40.6 \%(33.4-48.3 \%) \\ \text { Fu YF, 2009 [119] } & 2008 & 40.4 \%(35.4-45.6 \%) \\ \text { Su MF, 2010 [101] } & 2009 & 18.9 \%(14.8-23.7 \%)\end{array}$

CD4+ cell increase in $\mathrm{HIV}$-infected people receiving antiretroviral therapy [137]. It is therefore a high priority to provide necessary healthcare and treatment for coinfected individuals in parallel to the roll-out of MMT in China.

Several limitations in this study should be noted. First, by the end of November 2010, there were 696 MMT clinics in China, covering 27 Chinese provinces [138], however, out of these, eight provinces did not publish any reports on the prevalence of HIV or HCV. Furthermore, estimates of HIV or HCV prevalence from Beijing, Henan, Hebei, Ningxia and Qinghai provinces were based on only one report. These may likely contribute to bias of the overall regional or national prevalence.

Table 3 Summary of HIV-HCV Co-infection among clients in MMT in China

\begin{tabular}{|c|c|c|c|c|c|c|}
\hline Groups & Provinces & $\begin{array}{c}\text { No of } \\
\text { studies }\end{array}$ & $\begin{array}{l}\text { Study } \\
\text { Year }\end{array}$ & $\begin{array}{c}\text { Prevalence (individual } \\
\text { studies) }(95 \% \mathrm{CI})\end{array}$ & $\begin{array}{c}\text { Pooled prevalence } \\
\text { (provinces) }(95 \% \mathrm{Cl})\end{array}$ & $\begin{array}{l}\text { Pooled prevalence } \\
\text { (group) }(95 \% \mathrm{Cl})\end{array}$ \\
\hline \multirow[t]{13}{*}{ HTAs } & Guangxi & 3 & & & $12.6 \%(4.0-33.4 \%)$ & $8.0 \%(4.8-12.9 \%)$ \\
\hline & Zhou XP, 2009 [31] & & 2007 & $11.2 \%(7.2-16.9 \%)$ & & \\
\hline & Chang ZR, 2010 [32] & & 2008 & $27.4 \%(24.7-30.2 \%)$ & & \\
\hline & Bai Y, 2009 [33] & & 2009 & $5.8 \%(4.1-8.2 \%)$ & & \\
\hline & Guizhou & 3 & & & $3.8 \%(0.4-29.3 \%)$ & \\
\hline & Chang ZR, 2010 [32] & & 2008 & $23.1 \%(20.0-26.5 \%)$ & & \\
\hline & Wang J, 2010 [36] & & 2009 & $0.7 \%(0.1-4.8 \%)$ & & \\
\hline & $\operatorname{Han}$ XJ, 2010 [34] & & 2009 & $2.0 \%(0.9-4.4 \%)$ & & \\
\hline & Sichuan & 4 & & & $6.8 \%(2.8-15.8 \%)$ & \\
\hline & Qian HZ, 2007 [38] & & 2005 & $13.5 \%$ (10.9-16.6\%) & & \\
\hline & Dong G, 2009 [41] & & 2007 & $3.4 \%(2.0-5.9 \%)$ & & \\
\hline & Wang DY, 2010 [120] & & 2008 & $19.2 \%(16.4-22.3 \%)$ & & \\
\hline & Yao W, 2008 [44] & & 2008 & $1.9 \%(1.1-3.2 \%)$ & & \\
\hline \multirow[t]{16}{*}{ LTAs } & Chongqing & 2 & & & $5.3 \%(1.9-13.9 \%)$ & $2.5 \%(1.4-4.4 \%)$ \\
\hline & Zhou X, 2009 [60] & & 2007 & $8.7 \%(6.6-11.2 \%)$ & & \\
\hline & Wu GH, 2010 [59] & & 2008 & $3.1 \%(2.1-4.5 \%)$ & & \\
\hline & Fujian & 1 & & & $1.0 \%(0.1-6.8 \%)$ & \\
\hline & Wu LH, 2007 [61] & & 2006 & $1.0 \%(0.1-6.8 \%)$ & & \\
\hline & Gansu & 1 & & & $0.8 \%(0.2-3.2 \%)$ & \\
\hline & Gao LF, 2010 [63] & & 2009 & $0.8 \%(0.2-3.2 \%)$ & & \\
\hline & Guangdong & 2 & & & $1.9 \%(0.9-3.8 \%)$ & \\
\hline & Li YF, 2009 [72] & & 2008 & $2.5 \%(1.0-5.9 \%)$ & & \\
\hline & Xia L, 2010 [77] & & 2009 & $1.2 \%(0.4-3.7 \%)$ & & \\
\hline & Henan & 1 & & & $0.5 \%(0.1-3.2 \%)$ & \\
\hline & Wu SX, 2009 [78] & & 2008 & $0.5 \%(0.1-3.2 \%)$ & & \\
\hline & Hunan & 1 & & & $6.8 \%(4.8-9.4 \%)$ & \\
\hline & Chen LF, 2009 [83] & & 2009 & $6.8 \%(4.8-9.4 \%)$ & & \\
\hline & Jiangsu & 1 & & & $1.0 \%(0.2-3.7 \%)$ & \\
\hline & Wang YP, 2009 [87] & & 2007 & $1.0 \%(0.2-3.7 \%)$ & & \\
\hline
\end{tabular}


Table 4 Result of individual variable meta-regression models for each stratified meta-analysis

\begin{tabular}{|c|c|c|c|c|c|c|}
\hline \multicolumn{7}{|c|}{ Stratified meta-analyses } \\
\hline \multirow[t]{3}{*}{ Study Characteristic } & \multicolumn{2}{|c|}{ HIV prevalence } & \multicolumn{2}{|c|}{ HCV prevalence } & \multicolumn{2}{|c|}{ HIV-HCV co-infection prevalence } \\
\hline & Pooled estimate & Meta-regression & Pooled estimate & Meta-regression & Pooled estimate & Meta-regression \\
\hline & $\%(95 \% \mathrm{Cl}), \mathrm{n}$ & ( $\beta, p$-value) & $\%(95 \% \mathrm{Cl}), \mathrm{n}$ & ( $\beta, p$-value) & $\%(95 \% \mathrm{Cl}), \mathrm{n}$ & $(\beta, p$-value) \\
\hline \multicolumn{7}{|l|}{ Language of article: } \\
\hline Chinese & $6.0(4.7-7.6), n=70$ & 0.060 & $60.1(52.6-67.2), n=69$ & 0.018 & $4.2(2.5-6.8), n=18$ & 0.402 \\
\hline English & $8.4(2.7-23.0), n=2$ & $p=0.956$ & $57.9(35.9-77.1), n=2$ & $p=0.964$ & $13.5(10.9-16.6), n=1$ & $p=0.823$ \\
\hline \multicolumn{7}{|l|}{ Sample size: } \\
\hline$<500$ & $4.8(3.4-6.7), n=50$ & 0.178 & $59.8(54.6-64.9), n=53$ & -0.189 & $2.2(1.2-4.1), n=11$ & 1.367 \\
\hline$\geq 500$ & $8.2(5.6-11.8), n=22$ & $p=0.561$ & $60.3(42.3-75.8), n=18$ & $p=0.191$ & $9.8(5.7-16.2), n=8$ & $p=0.029$ \\
\hline \multicolumn{7}{|l|}{ Study locations*: } \\
\hline HTA & $17.5(14.0-21.6), n=27$ & -1.811 & $70.2(62.6-76.8), n=21$ & -0.335 & $8.0(4.8-12.9), n=10$ & -0.831 \\
\hline LTA & $2.4(1.6-3.5), n=45$ & $p<0.001$ & $55.5(46.4-64.2), n=50$ & $p=0.017$ & $2.5(1.4-4.4), n=9$ & $p=0.139$ \\
\hline \multicolumn{7}{|l|}{ Sampling method: } \\
\hline Cross-sectional & $5.7(4.3-7.4), n=580$ & 0.148 & $62.4(54.2-69.9), n=60$ & -0.275 & $4.6(2.9-7.2), n=19$ & - \\
\hline Others & $8.3(5.1-13.2), n=14$ & $p=0.686$ & $46.2(36.3-56.5), n=11$ & $p=0.112$ & - & - \\
\hline \multicolumn{7}{|l|}{ Time period: } \\
\hline $2004-2006$ & $8.0(5.2-12.2), n=16$ & -0.268 & $56.7(47.0-65.8), n=13$ & 0.026 & $4.5(0.3-40.4), n=2$ & 0.353 \\
\hline $2007-2010$ & $5.5(4.1-7.3), n=56$ & $p=0.458$ & $60.9(52.1-69.0), n=58$ & $p=0.879$ & $4.4(2.7-7.2), n=17$ & $p=0.803$ \\
\hline
\end{tabular}

Table showing the pool estimate (\%), 95\% confidence interval (Cl), number of studies (n), meta-regression coefficient ( $\beta$ ) and significance of $\beta$ ( $p$-value). $p$-values in bold print represent significant associations $(p<0.10)$.

* Study locations were categorized into two regions. HTA (high HIV transmission areas among DUs): Yunnan, Guizhou, Sichuan, Guangxi and Xinjiang; LTA (low HIV transmission areas among DUs): all provinces except above in Chinese mainland.

Further investigations in more cities are necessary to provide a more accurate description of HIV and $\mathrm{HCV}$ epidemics. Second, our study was focused on HIV and HCV infections among the same study cohorts, studies reporting only HIV or HCV prevalence estimates were excluded in this review and hence some significant studies might be missing in the stratified meta-analyses. Third, there are also a potentially large number of governmental documents, community-level reports and other unpublished data that have never been archived in any of the public literature databases. Fourth, we identified that the presence of high heterogeneities may be attributable to demographical differences in HIV and HCV prevalence among MMT clients across different Chinese geographical regions, but not the language of article, sampling method and study time may not explain the variations observed. It is important to note that other unreported factors, such as age, socio-economic status and sexual behaviours, may also be contributable to the heterogeneities.

\section{Conclusions}

Our study has several important implications to the future implementation of MMT in China. First, despite a rapid and substantial expansion of MMT program coverage in China $[124,139]$ the proportion of HIV- and $\mathrm{HCV}$-infected drug users attending MMT remains low.
Although MMT is beneficial at an individual-level, it can potentially be an effective population-level intervention strategy. Future expansion of MMT should target the infected population, as only inclusion of a large proportion of these infected individuals may substantially reduce their risk behaviours and maximize the preventive effects of MMT at a population level. Second, MMT should not be viewed as a replacement for other harm reduction programs, such as, needle and syringe exchange programs (NSEPs). A previous study has demonstrated that NSEPs in China are both effective and cost-effective for HIV prevention [3]. MMT should be rolled-out in conjunction with NSEPs to reduce the number of new infections. Third, as a result of high percentage of HCV co-infection among HIV-infected MMT clients at baseline of the treatment, other programs that providing treatment to HIV and HCV infected patients should also be provided to MMT clients. Fourth, the greater risk of IDUs being infected with HIV and HCV and reported relapse to drug usage may be a contributing factor to low retention in MMT $[140,141]$. It is therefore important for MMT to ensure sufficient support and care is provided for enrolled IDUs to maintain their behavioural changes. Peer-group support and frequent counseling follow-ups may be beneficial in building motivating environment for abstinence from addictions. 


\section{Additional file}

Additional file 1: Figure S1. Forest Plot showing the results of metaanalysis of HIV prevalence among clients in MMT $(\mathrm{N}=72)$. Figure S2. Forest Plot showing the results of meta-analysis of HCV prevalence among clients in MMT $(\mathrm{N}=71)$. Figure S3. Forest Plot showing the results of meta-analysis of HIV-HCV co-infection prevalence among clients in MMT ( $N=19)$. Table S1. Quality assessment score of all studies $[31,32,34-53,55-109,111,113-120]$.

\section{Competing interests}

The authors declare that they have no competing interests.

\section{Author's contributions}

All authors were involved in the study design, including setting up the keywords search and project protocol. XZ and EPFC performed the literature search, quality assessment and data extraction. EPFC performed data analysis. YFW and YXL assisted with data collection, DPW and LZ assisted with data analysis and interpretation. ZX drafted the manuscript. LZ was responsible for the supervision of the project. All authors read and approved the final manuscript.

\section{Acknowledgements}

This study was funded from the following sources: Round 8 of the AusAID Australian Leadership Awards (ALA) Fellowships Program; Overseas Scholarship of Jiangsu Government, China; Nantong University, Jiangsu province, China; The University of New South Wales; Australian Research Council (FT0991990); Graduate student science and technology innovative project of Nantong University (YKC12035).

\section{Author details}

${ }^{1}$ School of Public Health, Nantong University, Jiangsu Province, China. ${ }^{2}$ The Kirby Institute, University of New South Wales, Sydney, Australia.

Received: 28 November 2011 Accepted: 2 May 2012

Published: 8 June 2012

\section{References}

1. YanPing B, ZhiMin L: Current situation and trends of drug abuse and HIV/ AIDS in China. HIV Therapy 2009, 3(3):237-240.

2. Liu Z, Lian Z, Zhao C: Drug use and HIV/AIDS in China. Drug Alcohol Rev 2006, 25:173-175.

3. Zhang $L$, Yap $L$, Xun Z, Wu Z, Wilson D: Needle and syringe programs in Yunnan, China yield health and financial return. BMC Public Health 2011, 11(1):250.

4. China Ministry of Health and UN Theme Group on HIV/AIDS in China: A Joint Assessment of HIV/AIDS Prevention, Treatment and Care in China, 2003. 2003.

5. Zhu QY: Analysis of data AIDS sentinel surveillance from 1996 to 2003 in Guangxi province. CHIN J AIDS STD 2006, 12(5):290-432.

6. State Council AIDS Working Committee Office UN Theme Group on AIDS in China: A Joint Assessment of HIV/AIDS Prevention,Treatment and Care in China,2007. 2007

7. Chen J, Alberto D, Min TJ, An ZH, An Q, Ambrose DJ, Min J, Muncho NY: Analysis of data AIDS sentinel surveillance in Xinjiang province 2005. Endemic Disease Bulletin 2007, 22(02):55-56.

8. Li QP, Chen R, Huang L, Teng XY, Yuan K: Analysis of HIV prevalence from 1997 to 2006 in Anshun City. CHIN J AIDS STD 2008, 14(3):270-271.

9. $\quad$ Yang L, Li J, Zhang Y, Li H, Zhang W, Dai F, Ren Z, Qi G, Cheng W: Societal perception and support for methadone maintenance treatment in a Chinese province with high HIV prevalence. Am J Drug Alcohol Abuse 2008, 34(1):5-16.

10. Zhang $\mathrm{H}$ : Monitoring results of HIV among drug users in Zhenning coutry of Guizhou province. Modern Preventive Medicine 2010, 37(09):1717-1718.

11. Qian HZ, Vermund SH, Wang N: Risk of HIV/AIDS in China: subpopulations of special importance. Sex Transm Infect 2005, 81(6):442-447.

12. Tan Y, Wei QH, Chen $\amalg$, Chan PC, Lai WS, He ML, Kung HF, Lee SS: Molecular epidemiology of HCV monoinfection and HIV/HCV coinfection in injection drug users in Liuzhou, Southern China. PLoS One 2008, 3(10):e3608.
13. Xia X, Lu L, Tee KK, Zhao W, Wu J, Yu J, Li X, Lin Y, Mukhtar MM, Hagedorn CH, et al: The unique HCV genotype distribution and the discovery of a novel subtype $6 \mathrm{u}$ among IDUs co-infected with HIV-1 in Yunnan, China. J Med Virol 2008, 80(7):1142-1152.

14. Bao YP, Liu ZM: Systematic review of HIV and HCV infection among drug users in China. Int J STD AIDS 2009, 20(6):399-405.

15. Li H, Goggins W, Lee SS: Multilevel analysis of HIV related risk behaviors among heroin users in a low prevalence community. BMC Public Health 2009, 9:137.

16. Zheng X, Tian C, Choi KH, Zhang J, Cheng H, Yang X, Li D, Lin J, Qu S, Sun X, et al: Injecting drug use and HIV infection in southwest China. AIDS 1994, 8(8):1141-1147.

17. Fang $Y X$, Wang YB, Shi J, Liu ZM, Lu L: Recent trends in drug abuse in China. Acta Pharmacol Sin 2006, 27(2):140-144.

18. Guo W, Qu SQ, Ding ZW, Yan RX, Li DM, Wang L: Situations and trends of HIV and syphilis infections among drug users in China, 1995-2009. Zhonghua Liu Xing Bing Xue Za Zhi 2010, 31(6):666-669.

19. Jia M, Luo H, Ma Y, Wang N, Smith K, Mei J, Lu R, Lu J, Fu L, Zhang Q: The HIV epidemic in Yunnan province, China, 1989-2007. JAIDS Journal of Acquired Immune Deficiency Syndromes 2010, 53:S34.

20. Wang NC, Qiao XC, Zhang LF: Seroepidemiology of HCV infection among different populations in Shanxi. China Public Health 2001, 17(8):703.

21. Yang J, Ding JJ, Yang L: Co-infection with HCV and HGV among 107 injection drug users. Chin J Prev Med 2000, 34:85.

22. Deng LP, Gui XE, Zhang YX: A survey of HIV, HBV, HCV, HGV and TTV infections among drug abusers in Hubei Province. Hubei J Prev Med 2003, 14(5):1-2.

23. Li WJ, Fan ZF, Pan LJ: A survey of HIV and HCV infections and related knowledge and behavioramong drug abusers in Yangjiang City. South China. Prev Med 2004, 30(5):17-19.

24. Pang L, Hao Y, Mi G, Wang C, Luo W, Rou K, Li J, Wu Z: Effectiveness of first eight methadone maintenance treatment clinics in China. AIDS 2007, 21:S103.

25. Wu Z, Luo W, Sullivan SG, Rou K, Lin P, Liu W, Ming Z: Evaluation of a needle social marketing strategy to control HIV among injecting drug users in China. AIDS 2007, 21:S115.

26. Lau JTF, Zhang L, Zhang Y, Wang N, Lau M, Tsui HY, Zhang J, Cheng F: Changes in the prevalence of HIV-related behaviors and perceptions among 1832 injecting drug users in Sichuan, China. Sex Transm Dis 2008, 35(4):325.

27. Yin W, Hao Y, Sun X, Gong X, Li F, Li J, Rou K, Sullivan SG, Wang C, Cao X, et al: Scaling up the national methadone maintenance treatment program in China: achievements and challenges. Int J Epidemiol 2010, 39(Suppl 2):ii29-ii37.

28. China Ministry of Health, Ministry of Public Security and the State Food and Drug Administration: Opium abusers community-based drug maintenance treatment protocol (trial version). Beijing 2006.

29. Moher D, Liberati A, Tetzlaff J, Altman DG: Preferred reporting items for systematic reviews and meta-analyses: the PRISMA statement. PLoS Med 2009, 6(7):e1000097.

30. Boyle MH: Guidelines for evaluating prevalence studies. Evid Based Ment Health 1998, 1(2):37-39.

31. Zhou XP, He CN, Wei XY: Infection of HBV, HVC, HIV and syphilis at methadone maintenance treatment. Strait J Prev Med 2009, 15(3):80-81.

32. Chang RZ, Yin WY, Huang YM, Yao YM, Pang L, Wu ZY: A survey of HIV, $\mathrm{HCV}$,syphilis and HSV-2 among drug users attending methadone maintenance clinics in Guangxi and Guizhou. CHIN J AIDS STD 2010, 16(05):470-472. +505.

33. Bai Y, Lai WS, Wei L: Prevalence of HIV, HCV and Syphilis Infection at Methadone Maintenance Treatment Clinic in Liuzhou City. J Prev Med Inf 2009, 25(11):910-912.

34. Han XJ, Xu YX, Jiang HM, He J, Tan B, Cao FB: Infection of HIV, HBV, HCV and syphilis in 300 drug abusers in Guiyang City. Chin J Drug Depend 2010, 19(2):116-119.

35. Li XY, Mou X, Luo JQ: Detection monitoring and analysis of HCV, HBC and HIV at methadone maintenance treatment. Chinese journal of drug abuse prevention and treatment 2009, 15(5):283-284.

36. Wang J, Yang XJ: Prevalence ofH IV, HCV Infecti on and Syphilis Among Drug Users at Methadone Maintenance Clinics in Anshun. Journal of Occupational Health and Damage 2010, 25(3):145-148. 
37. Hao C, Hu W, Ruan YH, Ma ZE, Yang XG, Zhang L, Yin L, Liu SZ, Chen KL, Qin GM, et al: Impact of community-based methadone maintenance treatment on high risk sexual behaviors among heroin addicts. CHIN J AIDS STD 2006, 12(4):307-310.

38. Qian HZ, Hao C, Ruan Y, Cassell HM, Chen K, Qin G, Yin L, Schumacher JE, Liang S, Shao Y: Impact of methadone on drug use and risky sex in China. J Subst Abuse Treat 2008, 34(4):391-397.

39. Chen $B$, Luan RS, Jiang HY, Yu G: Investigation on AIDS related KAP among drug users in Yibin. Morden Prevention Medicine 2009, 36(03):502-504. + 508.

40. Liu JK, Li LH, Chen YH, Liu D, Li I, Luo W: Evaluation of methadone maintenance treatment for heroin users in Panzhihua. J Prev Med Inf 2009, 25(9):723-725.

41. Dong G, Jia H: H IV, HCV and Syphilis Infection Among Drug Users in Luzhou City. J Prev Med Inf 2009, 25(1):55-57.

42. Wang $Y$ : Data analysis of 715 methadone maintenance treatment in Luzhou City. Prev Med Trib 2009, 15(06):553-554

43. Wang DY, Chen YM, Huang QL, Zhou M, Chen HM, Pan L: Infection and risk factors of HIV and HCV among drug users in Zigong City. South China J Prev Med 2009, 04:38-40.

44. Yao W, Jiang ZH, Jia SG, Yang H, Liao KK: Prevalence of HIV, HCV and syphilis infection at methadone maintenance treatment clinic in Mianyang city. J Prev Med Inf 2008, 24(7):498-500.

45. Liu JB, Dilixiat YAHAP, Li F: Baseline Investigation on Community Methadone Maintenance Treatment of Heroin Addicts in Urumqi. Endemic Disease Bulletin 2006, 21(1):39-43.

46. Fu LP, Li F, Zhang ZZ, Mo LR: Effective evaluation on parts of communitybased methadone maintenance treatment clinics for heroin addicts in Xinjiang. Endemic Disease Bulletin 2007, 22(5):17-19.

47. Fang HR, Mo LR, Liu JX: Analysis of test results of HIV and HCV in methadone maintenance treatment clinic. Chinese Community Doctors 2008, 10(16):137.

48. Reziwa NuErLa, Ailikemu YaHePu, Tian Y: Investigation on herion addicts of Han and Uygur nationality with methadone maintenance. Endemic Disease Bulletin 2009, 05:8-10

49. Shen $L$, Du XJ, Fang HT: Analysis the reason of the dropout in the process of the 992 cases on methadone maintenance treatment. China Prac Med 2009, 4(30):39-40.

50. Yuan L, Dai JH, Tian Y: Diliyati.Yahepu: Investigation on community methadone maintenance treatment on 200 herion addicts in Xinjiang. Endemic Disease Bulletin 2010, 02:16-19.

51. Duan YJ, Yin ZL, Xi CD, Li ZC, Gao Y: Effect assessment of methadone maintenance treatment among heroin addicts in Ruili city. CHIN J AIDS STD 2008, 14(3):240-242.

52. Zhang MJ, Wang GX, Wang WZ, Sun YH, Du JQ, Tang L, Xue SY, Bi AM: Baseline survey analysis of methadone maintenance treatment in Kaiyuan. Soft Science of Health 2008, 22(3):273-274.

53. Zhuang HY, Xun JP, Li XT, Deng HC, Cao HL, Dai LH, Chen F, Cao LH, Chen QY: Analysis of reusing herion by patients with physical diseases when on methadone maintenance treatment. Chin J Drug Depend 2008, 17(5):377379.

54. Xue HM, Duo L, Yang LH, Zhao XZ, Zhong JR, Lei YJ, Ruan Y, He LP, Wang LM: et al: An analysis of impact factors related with needle sharing among MMT clients. CHIN J AIDS STD 2010, 06:548-550

55. Yang GW, Yin ZL, Li ZL, Peng KJ, Xi CH, Yang YB, Li ZC, Duan YJ: Analysis Of reasons for patients leaving methadone maintenance treatment mobile pilot service vehicles in Ruili City. Chinese journal of drug abuse prevention and treatment 2010, 16(2):83-85.

56. Yang YC, Duan S, Xiang LF, Ye RH, Gao J, Yang SS, Yang YB: Adherence and related determinants methadone maintenance treatment among heroin addicts in Dehong prefecture, Yunnan province. Chin J Epidemiol 2011, 32(2):125-129.

57. Du WJ, Xiang YT, Wang ZM, Chi Y, Zheng Y, Luo XN, Cai ZJ, Ungvari GS, Gerevich J: Socio-demographic and clinical characteristics of 3129 heroin users in the first methadone maintenance treatment clinic in China. Drug Alcohol Depend 2008, 94(1-3):158-164.

58. Tan $X L$, Luo BS, Zhu LX: Investigation on AIDS related KAP among drug users in Chongqing. Morden Preventive Medicine 2007, 34(6):1152-1153.

59. Wu GH, Chen H, Meng X, Zhou C: Epidemiological survey on the HCV and HIV infection among drug users in Chongqing City. Morden Preventive Medicine 2010, 37(1):134-136.
60. Zhou X, Zhang X, Zhou XM: HIV, HCV examination data analysis among drug users treated with oral methadone maintenance in Panzhihua City from 2005 to 2007. Prev Med Trib 2009, 15(08):745-746.

61. Wu LH, Chen HM: Infection of HBV, HCV. HIV and syphilis at methadone maintenance treatment in Quanzhou city. CHIN J AIDS STD 2007, 6:573.

62. Zheng WX, Chen G: Baseline investigation on methadone maintenance treatment of 334 drug users. Strait J Prev Med 2009, 15(3):34-35.

63. Gao LF, Yang J, Li SJ: Detection and analysis of HIV, HBV, syphilis and HCV infections of methadone clinic in Jinchang City. Chinese Community Doctors 2010, 12(14):168.

64. Zhu XH, Xun JP, Gao L, Peng JJ: Monitoring and analysis of clinical blood in 613 MMT clients. Chinese journal of drug abuse prevention and treatment 2010, 16(6):340-342.

65. Dai $L P, L u$ J, Jiang $T$, Jiang LH, Qiu XL: Investigation and analysis of konwledge of HIV among drug users in methadone maintenance treatment. Chin J of PHM 2009, 01:83-84.

66. Liu XY, Wu B: Analysis of 2007 drug abuse monitor reports in Shenzhen. Chinese journal of drug abuse prevention and treatment 2009, 15(1):30-33.

67. Zhang QL: A baseline investigation on herion addicts in methadone maintenance treatment clinics in Dongguan. Chin J Drug Depend 2008, 17(3):204-207

68. Chen W, Zhao LL, Ling L, Chen A, Xia YH, Han L, Lin P, He Q: Effectiveness evaluation on initial methadone maintenance treatment at community in Guangdong province. Chin J Public Health 2009, 12:1416-1418.

69. Chen A, Xia YH, Chen W, Ling L, Tan WK, Zheng RJ: Predictors of retention related factors at the initial methadone maintenance treatment clinics in Guangdong province. Chin J Epidemiol 2009, 30(12):1230-1233

70. Dai LP, Lin SX, Jiang YH, Gong CH: Research of 257 herion addicts in community methadone maintenance treatment. Chin J of PHM 2010, 26(004):417-419.

71. Hu WS, Wang DP, Huang $X$, Zheng HB, Peng ZT: Analysis of the efficacy of medicine(methadone) maintenance treatment in 125 cases of heroin dependence patients. Chinese journal of drug abuse prevention and treatment 2010, 16(2):86-88.

72. Li LY, Qiu YM, Guo JH, Xie ZQ: Effect of health education on therapy compliance of methadone maintenance treatment. Int J Nurs 2009, 28(6):837-839.

73. Li YF, Luo CQ, Ding GP: Investigation of the prevalence of the HIV and HCV infection in methadone maintenance treatment in Dongguan. Morden Hospital 2009, 9(3):155-156.

74. Wang M, Lin P, Zhao JK, Li Y, Zhang QL: Correlation Analysis of drug Abuse Sexual Behaviours and Other Risk Factors in the CommunityBased drug Addicts. Journal of Tropical Medicine 2009, 9(11):1291-1294.

75. Wang CQ, Liang QS, Xie HL, Su M, Xu TX: Analysis of methadone treatment compliance. IMHGN 2009, 15(14):78-80.

76. Wu ZL, Huang $Y L$, Guo LZ: Baseline survey analysis on drug users in methadone maintenance treatment clinics from Doumen area of Zhuhai City. Guide of China Medicine 2010, 08(16):84-85.

77. Xia L, Zhang QS, Deng XL, Li CX, Shen J, Liu T, Cai CL, Liu WH, Chen YQ, Yang M: Prevalence of HIV, HCV and Syphilis among heroin addicts at methadone maintenance treatment clinic in Shenzhen city. Chinese journal of drug abuse prevention and treatment 2010, 16(2):63-65.

78. Wu SX: Baseline Investigation Analysis of Methadone maintenance treatment in Sanmenxia community. Henan medical research 2009, 18(3):248-250.

79. Qiu XQ, Zhou B, Xu M, Tao YB, Wen YM, Wen MX: Investigation into the AIDS knowledge, behavior and serological test among the drug users in Xiangfan. Chinese Journal of Disease Contral and Prevention 2009, 13(4):493495.

80. Li XL, Ou QY, Tan HZ, Sun ZQ, Zhang H, Chen MS: Investigation on the drug abuser in methadone maintenance treatment clinic in Changsha. Chin J Dis Control Prev 2008, 12(1):27-29.

81. Li XL, Tan HZ, Sun ZQ, Zhang H, Chen MS, Ou QY: Study on the time of retention and related influencing factors of patients receiving methadone maintenance treatment in Hunan province. Chin J Epidemiol 2009, 30(7):672-675.

82. Tang XY, Li J, Huang $X$, Duan KM, He LP: Baseline investigation on herion addicts of methadone maintenance treatment in Chenzhou City. Practical Prevention Medicine 2007, 14(4):1263-1264.

83. Chen LF: Survey of infectious status of HIV, HBV, syphilis and HCV on 459 drug users. Practical Preventive Medicine 2009, 16(5):1641-1642. 
84. He HX, Bao YG, Chen LF, Li SX, Xiang CQ, Xie X, Zhang DQ: Effect of MMT on reducing the transmission of HIV among IDUs. CHIN J AIDS STD 2008 14(2):124-126

85. Chen C: Analysis of hydrochloric acid Methadone Maintenance Treatment for Heroin Addicts. Chinese Community Doctors 2010, 12(33):142-143.

86. Feng YH, Han L, Cui R, Chen DQ, Zhu JH, Fang MS, Xu SQ: General information about patients undergoing methadone maintenance treatment in Wuhan. Journal of Nursing Science 2010, 25(23):70-71.

87. Wang YP, Zhang GP, Wang F: Survey on Infection of HBV, HCV and HIV among Addicts Receiving Methadone Therapy. Occupation and Health 2009, 25(24):2765-2766.

88. Feng SQ, Zhou JB, Guo YL, Shi TP, Li JH, Xu XG, Chen SL, Hao C: Effective evaluation of community-based methadone maintenance treatment for heroin addicts. Chin J Public Health 2010, 26(7):924-925.

89. Hao C, Zhou JB, Li JH, Xu W, Liu SF, Ji XH, Xu XG, Chen XG: Influencing factors associated with behavior characteristics of drug abuse in a community-based methadone maintenance treatment among drug users. Chin J Public Health 2009, 25(7):781-783.

90. $\mathrm{Xu} \mathrm{GY}$ : A baseline investigation on newly enrolling drug users and community drug users from Baixia Area methadone clinics of Nanjing City. Jiangsu Health Care 2008, 10(6):6-7.

91. Zhang MH, Liu XX, Xu KY, Shan L: Epidemiological Investigation on Drug Abusers in Community Methadone Mai ntenance Treatment Clinic in Zhen jiang City. Occup Health 2010, 26(20):2335-2337.

92. Yuan ZX, Qiu HX, Mei ZF: Analysis on 226 cases of out-patient methadone treatment of viral hepatitis syphilis. HIV infection detection among drug addicts in Yandu District. Prev Med Trib 2010, 07:601-602.

93. Jiang A, Zhao JH, Wang XZ, Han QQ, Chen SG, Hu XL: Effect analysis of the heroin addicts with methadone maintenance treatment in experimental units of Wuzhong in Ningxia. Modern Preventive Medicine 2009, 15:2920-2922

94. Hao XQ: Survey on infection of HIV and HCV among 277cases of methadone maintenance treatment. Qinghai Medical Journal 2009, 06:75-76.

95. Jia W, Ye ZS, Zhang R, Wang RQ: Analysis of dose-effect relationship and compliance for methadone maintenance treatment. Chinese journal of drug abuse prevention and treatment 2008, 14(5):253-256.

96. Zhang HF, Deng KW, Zhang YF, Tong HY, Long HY: Efficacy evaluation on methadone maintenance treatment in Hanzhong Shanxi. Chin J Drug Depend 2009, 18(1):43-46.

97. Liu Y, Zhang YY, Zhang HF: Baseline investigation of OPD attendance among insisting Meishatong users in Putuo district Shanghai. Shanghai Journal of Preventive Medicine 2009, 21(9):429-430.

98. Li T, Shen WL, Xu XP, Zhou ZR: AIDS High Risk Behaviors Investigation in Patients Visiting Methadone Maintenance Clinic in Xuhui District. Guide of China Medicine 2010, 8(5):29-30.

99. Cai CP, Zhou ZM, Chen LX, Chen LX: Investigation of AIDS, hepatitis B and $\mathrm{C}$ among methadone-treated drug addicts women of childbearing age. Disease Surveillance 2008, 23(2):126-127.

100. Zhang $\mathrm{XH}$, Sun J: Denographic characteristics and drug abuse of 165 herion dependent patients on methadone maintenance treatment. Chin J Drug Depend 2008, 17(2):144-147.

101. Su MF: HIV, HCV and TB infection among drug users receiving methadone treatment in Yuhuan country, Zhejiang province. Disease Surveillance 2010, 04:302-304.

102. Wang J, Yang XJ: Survey of infectious status of HCV among drug users of methadone clinic in XIXIU area, ANSHUN CITY, in 2008. J Prev Med Inf 2010, 26(6):504-505.

103. Deng CK, Dong F, Sun HB, Xie MJ: Analysis of influencing factors and risk factors of liver function damage in herion addicts from MMT clinic in Qingzhen City. Chinese Journal of Abuse Prevention and Treatment 2009, 15(5):267-269

104. Zhao XH, Liao KK, Liu DC, Yang HW, Sun HY: Investigation of reasons of patient-loss in methadone maintenance treatment clinic. J Prev Med Inf 2009, 25(5):457-459.

105. Wang XR, Zhang F, Chen XN: Analysis of anti-HCV among drug users in Bengbu City. JPMT 2007, 14(18):2417-2418.

106. Zhan SW, Ding YX: Analysis of cucatinve effects of 215 herion addicts with methadone maintenance therapy in Maanshan. Anhui J Prev Med 2008, 04:241-242.
107. He XX, LV J, Wei HY: Analysis on relevant factors of HCV Screening Result of 1516 Heroin Addicts. Chinese journal of drug abuse prevention and treatment 2010, 16(3):154-157.

108. Peng JS, Zhou ZD, Pei DE, Zhou Y, Liu MQ, Tang L, Xu J, Wu XW, Huo WZ, Zhou W: Study on the distribution of hepatitis $C$ virus genotypes in patients visiting one methadone maintenance clinic in Wuhan. Chin J Epidemiol 2007, 28(12):1207-1210.

109. Xia X, Luo J, Dong J, You H, Qian YH, Qian XC, Yu RB: Epidemiological survey on the HCV infection among drug users in some areas of Jiangsu. Modern Preventive Medicine 2007, 34(24):4616-4618,4621.

110. Xu YP: Detection results of anti-HCV among drug replacement therapy patients in Wuxi city. Shanghai Journal of Preventive Medicine 2007, 19(1):12.

111. Song HB: Epidemiological survey on the HCV infection among drug users at methadone maintenance treatment in Nantong city. Medical Journal of Chinese People's Health 2010, 22(1):22-23.

112. Wang WM: Survey of HIV and HCV infection among drug users in Kunshan City. China Tropical Medicine 2010, 10(11):1362-1363.

113. Liu XP: Analysis of hepatitis C virus infection among 93 herion addicts in Zhongshan City. Chinese Journal of Coal Industry Medicine 2010, 13(12):1777.

114. Li YC, Jia W, Shen DH, Wang F, Zhang R: Analysis of influencing factors of $\mathrm{HCV}$ infection in drug users from methadone maintenance therapy clinic in Xi'an. Chinese journal of drug abuse prevention and treatment 2009, 15(4):207-209.

115. Zang JF, Li J, Zhang FQ, Zhai XM, Qiao Y, Luo C: Investigation on HCV infection among drug users in Methadone maintenance treatment. Chinese journal of drug abuse prevention and treatment 2010, 16(2):88-90

116. Liu HB, Zhe XL: Study on HCV co-infection in Yulin drug users. J Med Pest Control 2010, 08:731-732.

117. Du J, Wang Z, Zhang HH, Dong AZ, Fan CL, Yuan Y, Jiang HF, Zhao M: HCV knowledge and HCV infection among drug users treated in a methadone maintenance treatment clinic. Chin J Drug Depend 2009, 18(6):495-499.

118. Zhang $\mathrm{XH}$ : Analysis of 117 cases on methadone maintenance treatment. Chin J Drug Depend 2007, 16(2):140-142

119. Fu FY, Qian YP: Detection results of HIV, HCV and syphilis and behavior characteristics among 349 drug users in Hangzhou City. J of Radioimmunology 2009, 22(6):639-640.

120. Wang DY, Chen YM, Huang QL, Zhou M: Study in HIV/HCV co-infection in Zigong drug users. Modern Preventive Medicine 2010, 37(2):361-362.

121. GH L: The analysis on HIV surveillance among Guangxi IDUS in 20052007. Intern Med 2008, 3(3):325-326.

122. Liao KK, Zhao XH, Su J, Lui DC, Jia SG, Yang H, Yao W: AIDS surveillance among drug users in Mianyang 2009. J Prev Med Inf 2011, 27(02):94-96.

123. Zhang Q, Wu T, Huang Y, Tan DY, Xi DR: The analysis of sentinel surveillance among drug users from 2006 to 2010 in Shunqing district of Nanchong City. Parasitoses and Infectious Disease 2011, 9(01):38-40.

124. Liu EW, Liang T, Shen LM, Zhong H, Wang B, Wu ZY, Detels R: Impact of methadone maintenance treatment on HIV risk behaviors of heroin drug users. Zhonghua Yu Fang Yi Xue Za Zhi 2010, 44(11):981-984.

125. Joseph H, Stancliff S, Langrod J: Methadone maintenance treatment (MMT): a review of historical and clinical issues. Mt Sinai J Med 2000 67(5-6):347-364.

126. $\mathrm{Wu} J \mathrm{~L}, \mathrm{Wu} \mathrm{ZY}$ : The effectiveness of methadone maintenance treatment and related factors. Chinese Journal of AIDS/STD 2004, 10(001):69-70.

127. Tang Y, Zhao D, Zhao C, Cubells JF: Opiate addiction in China: current situation and treatments. Addiction 2006, 101(5):657-665.

128. Shi J, Zhao LY, Epstein DH, Zhang XL, Lu L: Long-term methadone maintenance reduces protracted symptoms of heroin abstinence and cue-induced craving in Chinese heroin abusers. Pharmacol Biochem Behav 2007, 87(1):141-145.

129. Sullivan SG, Wu Z: Rapid scale up of harm reduction in China. Int J Drug Policy 2007, 18(2):118-128.

130. Wang HP, Yang JJ, Deng XZ, Xu K, Wang J, Zhang Y: HIV/HBV/HCV infection among drug users: a meta analysis of data collected in Chinese mainland. Chin J Dis Control Prev 2010, 14(04):300-304.

131. Xu C, Pang L, Wu ZY: Human immunodeficiency virus and hepatitis $C$ virus infections among drug users in China. Chin J Dis Contr ol Pr ev 2009, 13(2):193-196

132. Aceijas C, Rhodes T: Global estimates of prevalence of HCV infection among injecting drug users. Int J Drug Policy 2007, 18(5):352-358. 
133. Sulkowski MS, Thomas DL: Hepatitis C in the HIV-infected person. Ann Intern Med 2003, 138(3):197.

134. Verucchi G, Calza L, Manfredi R, Chiodo F: Human immunodeficiency virus and hepatitis $C$ virus coinfection: epidemiology, natural history, therapeutic options and clinical management. Infection 2004, 32(1):33-46.

135. Garten RJ, Zhang J, Lai S, Liu W, Chen J, Yu XF: Coinfection with HIV and hepatitis $\mathrm{C}$ virus among injection drug users in southern China. Clin Infect Dis 2005, 41 (Suppl 1):S18-24.

136. Sulkowski MS, Thomas DL, Mehta SH, Chaisson RE, Moore RD: Hepatotoxicity associated with nevirapine or efavirenz?containing antiretroviral therapy: role of hepatitis $\mathrm{C}$ and $\mathrm{B}$ infections. Hepatology 2002, 35(1):182-189.

137. Choi SY, Cheung YW, Chen K: Gender and HIV risk behavior among intravenous drug users in Sichuan Province, China. Soc Sci Med 2006, 62(7):1672-1684

138. Ministry of Health: China has established key areas of drug addiction treatment covered by the network. 2010. http://wwwgoven/jrzg/2010-12/14/ content_1765546htm.

139. Mohamad N, Bakar NH, Musa N, Talib N, Ismail R: Better retention of Malaysian opiate dependents treated with high dose methadone in methadone maintenance therapy. Harm Reduct J 2010, 7:30.

140. Lai WS: Reasons for heroin dependent patients' dropout from methadone maintenance treatment. Chin J Drug Depend 2007, 16(4):299-301.

141. Wang B, Zhao J, Qian XC, Pan XW, Gao Q, Ding L: Reasons and influencing factors of patient-loss in methadone maintenance clinics in Wuxi. Chin J Epidemiol 2010, 31(2):238-239.

doi:10.1186/1471-2334-12-130

Cite this article as: Zhuang et al: HIV and HCV prevalence among entrants to methadone maintenance treatment clinics in China: a systematic review and meta-analysis. BMC Infectious Diseases 2012 12:130.

\section{Submit your next manuscript to BioMed Central and take full advantage of:}

- Convenient online submission

- Thorough peer review

- No space constraints or color figure charges

- Immediate publication on acceptance

- Inclusion in PubMed, CAS, Scopus and Google Scholar

- Research which is freely available for redistribution 